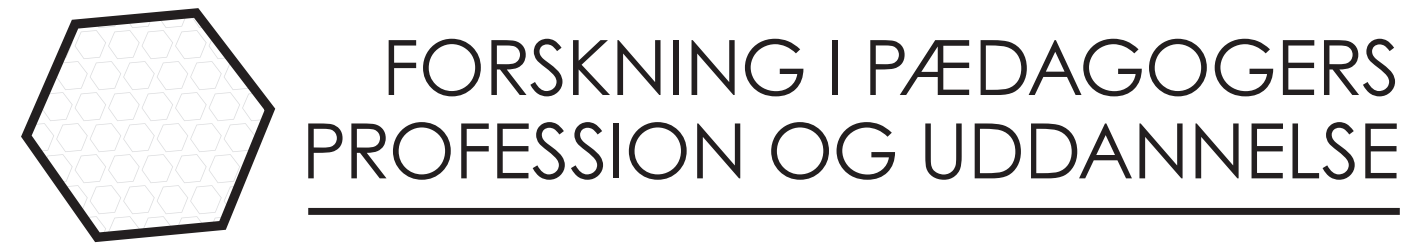

\title{
Sansen for at gøre det gode dannes gennem praksis
}

\author{
Brian Harring Boll \\ Cand.pæd. i pædagogisk filosofi. Lektor, \\ Professionshøjskolen UCN \\ bhb@ucn.dk
}




\title{
Resumé
}

Denne artikel tager afsæt i den antagelse, at en skolastisk tilgang til undervisningen i etik ikke er tilstrækkelig. Med afsæt i et aristotelisk og dannelsesteoretisk inspireret forsknings- og udviklingsprojekt undersøger artiklen værdien og meningsfuldheden $\mathrm{i}$ en alternativ didaktisk rammesætning af arbejdet med etik i uddannelse. Først beskrives den teoretiske og filosofiske inspiration til projektet, dernæst den didaktiske rammesætning. I forlængelse heraf analyseres projektets empiri, der primært er baseret på 15 pædagogstuderendes refleksioner over deres bestræbelser på at realisere en selvvalgt dyd i deres anden praktik. Det sker i lyset af projektets dannelsesteoretiske forståelseshorisont. Projektet viser bl.a., at de studerende finder koblingen mellem deres egen udviklingsproces og bestræbelsen på at realisere dyden særdeles meningsfuldt. De oplever, at dette øger deres selvindsigt, samt skærper og nuancerer deres blik for det etiske i praksis. Dette afføder normative overvejelser hos de studerende om, hvad de kan stå inde for i praksis, hvem de ønsker at være som pædagog, og hvad de må arbejde med for at kunne realisere det gode.

\begin{abstract}
The sense of doing good is formed through practice. This paper takes its starting point in the assumption that a scholastic approach to ethics education is insufficient. Based on a research and development project inspired by Aristotle's definition of virtues and Humboldt's theory of self-formation, this paper examines the value and meaningfulness of an alternative didactic framing of working with ethics in education. First the theoretical and philosophical inspiration for the project is described followed by a description of the didactic framework. Next comes an analysis of the project's empirical data, which is primarily based on the written reflections made by 15 social education students on their continuous efforts to realize a self-elected virtue during the second internship of their study programme. The analysis is conducted within the horizon of theory of self-formation. Among other things, the project demonstrates that the students find the linkage between their own development and their virtue-based endeavours highly meaningful. They feel that their efforts to realize their chosen virtue increase their self-insight and develop their eye for the many significant facets of practice. This in turn leads the students to make normative considerations about what they can vouch for in practice, who they want to be as social educators, and what they will have to focus on in order to be able to realise the good.
\end{abstract}

\section{Nøgleord}

Etik, professionsetik, professionsidentitet, dannelse, dyd, undervisningsudvikling. 
Keywords

Ethics, professional ethics, professional identity, formation, moral purpose, educational development

\section{Indledning}

En god analytiker er ikke nødvendigvis en god praktiker, der har sans for at gøre det gode. Det understregede den Harvarduddannede professor i filosofi og psykologi Bill Puka i et oplæg på Fourth International Conference on Ethics Education i Logroño 2016. Af konferencen fremgik det, at undervisning i etik og dømmekraft internationalt set og på tværs af professioner ofte består i en introduktion til etikkens klassikere pligt-, nytte- og dydsetik, der efterfølgende bruges i analyser af cases. Herigennem erhverver de studerende sig på skolastisk vis primært proportionel, ikke-personlig, ikke-kropslig viden og regelbaserede analytiske færdigheder (Wackerhausen 1997). I et aristotelisk- og dannelsesinspireret perspektiv er etik og dømmekraft dog i lige så høj grad baseret på det modsatte, det vil sige en ikke-proportionel, personlig, kropslig viden og sans for at gøre det gode i praksis. I tråd med dette peger Bjørn Ribers på, at en forudsætning for, at den professionelle kan stå fast på de professionsfaglige værdier, er, at professionalismen er udviklet gennem karakterdannelse og ud fra dydsetiske parametre. Uddannelse må ifølge Ribers ikke stå i modsætning til dette (Ribers 2018). En skolastisk tilgang til undervisningen i etik er i det lys ikke tilstrækkelig, og spørgsmålet er, hvordan den kan suppleres med henblik på en mere fyldestgørende uddannelsespraksis?

I artiklen sættes der fokus på en anderledes tematisering og rammesætning af emnet etik i professionsuddannelse. Dette sker med afsæt i et forsknings- og udviklingsprojekt, hvor pædagogstuderende med afsæt i deres egen selvforståelse blev bedt om at vælge en dyd, det være sig nærvær, tålmodighed m.v., som de personligt formodede ville blive udfordrende for dem at realisere i deres praktik. Hensigten var at udvikle en rammesætning, der kvalificerer de studerendes professionsfaglige virke i et etisk perspektiv.

Projektet byggede på en antagelse om, at en aristotelisk inspireret bestræbelse på at realisere dyden og gøre det gode ideelt set påvirker de studerendes etiske selv- og professionsfaglige verdensforhold, og derfor må forstås som en dannelsesproblematik.

Artiklen beskriver kort filosofien og teorien bag projektet, dernæst skitseres den didaktiske rammesætning, og i forlængelse heraf analyseres de studerendes erfaringer fra arbejdet med den selvvalgte dyd. Ifølge Wilhelm von Humboldts nyhumanistiske dannelsesbegreb forudsætter dannelse modtagelighed samt selvvirksomhed og herunder selvoverskridelse. Præmissen for artiklen er, at sådanne kvaliteter potentielt træder frem, når projektets empiri fortolkes i lyset af en dan- 
nelsesteoretisk forståelseshorisont, og artiklen undersøger, hvorvidt og hvorledes disse kommer til udtryk i de studerendes møde og arbejde med en selvvalgt dyd i praksis. Artiklen undersøger tillige hvorvidt et sådant arbejde og en sådan tematisering af etikken i uddannelsen opleves som meningsfuld af studerende og praktikvejledere.

\section{Empirisk og forskningsmetodisk grundlag}

Artiklen er baseret på empiri fra et forsknings- og udviklingsprojekt på pædagoguddannelsen i Aalborg. Projektet blev afviklet med 15 studerende over en periode på ca. 8 måneder med begyndelse i slutningen af 3. semester og som optakt til 2. praktik, der udgør hele 4 . semester til og med begyndelsen af 5. semester, hvor forløbet blev evalueret. Der er indsamlet empiri fra de øvelser og opgaver, som de studerende frivilligt har indgået i og afleveret før og under praktikken. 14 ud af 15 studerende har afleveret 3 opgaver i løbet af praktikken med praksisfortællinger og refleksioner over deres dydsarbejde. Derudover er der empiri fra den efterfølgende evaluering, og der er lavet et fokusgruppeinterview med fem praktikvejledere samt individuelle semistrukturerede interview med en tredjedel af de studerende kort efter projektets afslutning.

Projektets forskningsmæssige tilgang er hermeneutisk, og der er således tale om en fortolkning af det empirisk materiale. Det empiriske materiale repræsenterer i sig selv sprogligt formidlede udlægninger, og der antages derfor at være en afstand mellem empiri og praksis. Empirien udtrykker imidlertid den mening, de studerende tillagde de beskrevne oplevelser, og det er de heraf følgende erfaringer, som er blevet fortolket og analyseret i lyset af en dannelsesteoretisk forståelseshorisont. Dette er sket gennem kodning og meningskondensering (Brinkmann 2015) med særligt fokus på meningsfuldhed, selvvirksomhed, selvoverskridelse, samt de studerendes koblinger mellem deres selvforhold og professionsfaglige verdensforhold.

Hensigten med den dannelsesteoretiske forståelsesramme og det heraf følgende vokabular var at overskride den umiddelbare forstålse. Dette med henblik på at erhverve ny forståelse af, hvad der potentielt foregår i dannelsesmæssig henseende i en sådan uddannelses praksis, idet projektet bygger på en normativ antagelse om, at et øget fokus på og en stærkere vægtning af dannelsesprocesser i uddannelse er væsentlig.

Projektet er inspireret af Alexander von Oettingen og Merete Wibergs bud på og inspiration til empirisk dannelsesforskning (Oettingen 2018; Wiberg 2016, 2018), dog uden at dele ambitionen om at forbinde en åndsvidenskabelig inspireret normativ og teoretisk pædagogisktradition med de seneste årtiers dominerende angelsaksisk inspirerede forsknings- og empiriforståelse, idet dette projekt med sin hermeneutiske tilgang forbliver på det europæiske kontinent. Inspirationen ligger i stedet $\mathrm{i}$ den empiriske dannelsesforsknings opfordring til at efterprøve normative forestillinger empirisk i en søgen efter meningsfuld pædagogisk prak- 
sis (Oettingen 2018). Empirisk dannelsesforskning tager således afsæt i den moderne pædagogiks præmis, idet pædagogikken siden indgangen til det moderne har forudsat et teoretisk, normativt perspektiv, der fortløbende forholder sig til og revurderer pædagogikkens formål og gyldighed, men samtidig også et empirisk perspektiv, da den viden, der findes i erfaringen, er vigtig for den pædagogiske praksis. Pædagogik og pædagogisk forskning kan på den baggrund forstås som et eksperiment mellem de teoretiske og normative idealer og de empiriske erfaringer fra praksis. Inspireret af Dietrich Benner kan pædagogik i forlængelse heraf forstås som en eksperimenterende handlings- og erkendelsesform. Genstandsfeltet er menneskets dannelse (Oettingen 2018).

Wiberg peger på, at den teoretiske dannelsestænkning qua dens modeller, forestillinger og metaforer potentielt kan inspirere til nye forståelser af det pædagogiske verdensforhold, og at dette eventuelt kan efterprøves empirisk (Wiberg 2016). Det er denne inspiration og udfordring projektet har forsøgt at tage op. Ambitionen har været at opnå en større empirisk og praksisbaseret forståelse af, hvad der kan ske, når man lader didaktikken og tænkningen i og om praksis inspirere af filosofi og dannelsesteori. Sigtet og gyldighedskriteriet for projektet har således været at gøre en forskel (Flyvbjerg 2001) og bringe nye perspektiver til torvs, der ideelt set ville kunne inspirere til nye eksperimenter og udviklingen af meningsfuld uddannelsespraksis; men også mere konkret at udvikle en praksis, der kunne implementeres i uddannelsen, og som i højere grad end den traditionelle undervisning i etik kunne sætte de studerendes selvforhold i spil i relation til deres professionsetiske verdensforhold, støtte dem i at reflektere over dette, og hermed understøtte deres sans for og holdning til etisk praksis. Inden projektets didaktiske rammesætning udfoldes, skal den bagvedliggende dannelses- og dydsforståelse dog først beskrives.

\section{Projektets dannelsesforståelse}

Projektets dannelsesforståelse bygger på Humboldts dannelsesbegreb, som det er beskrevet af Wiberg (2018). Omend projektet handlede om dyder, og selvom Aristoteles' dydstænkning i sig selv var tænkt i et dannelsesperspektiv, så faldt valget på Humboldt, der var klart inspireret af Aristoteles (Straume 2013), men som i modsætning til Aristoteles teleologiske forståelse tænkte og forstod individets dannelse i overensstemmelse med pædagogikkens moderne præmis. I Humboldts optik står målet for det enkelte individs dannelse og fremtid således principielt åbent, hvorved pædagogikken ikke lader sig legitimere med den blotte henvisning til tradition og socialisation.

Et fælles referencepunkt i dannelsesteorier bredt set er, at dannelse vedrører forandringer i personligheden og altså i det enkelte individs selv- og verdensforhold (Wiberg 2018). Hos Humboldt er dannelsesprocessens katalysator mødet med 'det andet', som i princippet kan være alt, der adskiller sig fra det individ, dannelsen vedrører, og som rækker udover den enkeltes partikularitet. 'Det andet' afføder 
en vekselvirkning mellem dannelsesprocessens to momenter, som er henholdsvis modtagelighed og selvvirksomhed. Wiberg peger på, at der i disse to momenter ligger en normativ fordring til den, der ønsker at dannes. Modtagelighed fordrer implicit værdier som åbenhed og respekt, og selvvirksomhed fordrer muligheden for og udfoldelsen af værdier som frihed og autonomi. Karakteren af denne vekselvirkning og af individets forholdelsesmåde til 'det andet' eller verden som sådan er reguleret af omfanget af disse ideer/værdiers virkeliggørelse (Wiberg 2018).

Dannelse kan forbindes med rejsemetaforen. I dette projekt gik rejsen i retningen af mødet med en selvvalgt dyd i en konkret pædagogisk kontekst og bestod i en undersøgelse af, hvorledes realiseringen af denne dyd i forskellige kontekster stiller krav til den studerendes forholdelsesmåde.

Det at dannes er imidlertid ikke noget, man bare gør. Dannelse forudsætter også, at noget gøres ved én. Den studerende kan kun rette sin opmærksomhed og modtagelighed mod borgerne og den pædagogiske kontekst, hvori det gode søges realiseret, men hvorvidt denne kontekst så at sige 'taler' til den studerende, hvorvidt det, Klafki betegner som den dobbelte åbning, (Klafki 2011) indfinder sig, er usikkert. Derfor forudsætter dannelse vedholdenhed. Men selv når det andet 'taler' og gør indtryk, er det stadig usikkert, hvad dette medfører, hvorledes dette potentielt former og påvirker den enkelte studerendes etiske selv- og verdensforhold. Dannelsen eller dannelsens specifikke udkomme lader sig derfor ikke målsætte og kan i projektets optik ikke underkastes en mere specifik målstyring, da dette ville kvæle den frihed, der er den egentlige dannelses forudsætning.

\section{Inspirationen fra Aristoteles}

Aristoteles værk Etikken også kaldet Den Nikomacheiske etik består i en række undersøgelser. Centralt står spørgsmål som: Hvad er et godt menneske? Hvad driver dets handlinger?

Svaret er forenklet sagt, at det gode menneske er det dydige menneske. Idet dyder, også kaldet karakterdyder, er udtryk for en perfektion af menneskets handlinger. Dydsbestræbelsen var derfor forudsætningen for et vellykket liv også kaldet Eudaimonia. Eudaimonia kan ifølge Anne-Marie Søndergaard Christensen præciseres, som det der er ønskværdigt for et menneskeliv, når vi undersøger det i lyset af menneskelig godhed. Det ønskværdige opdager vi således, når vi forsøger at stræbe efter det gode (Christensen 2011).

I nærværende projektet var denne undersøgelse dels båret af refleksion over, hvad der må forstås som god socialpædagogisk praksis, dels af en vilje og bestræbelse på det, Aristoteles kaldte eupraxia - det 'at handle vel' eller 'den gode handling' (Aristoteles 2000). Denne stræben efter at handle vel, kan ligesom dannelse siges at være både mål og proces på en og samme tid. De studerendes bestræbelser bevirker således ideelt set, at de over tid danner en 'dydig karakter'. Med Aristoteles ord, "Således er det også ved at udføre retfordige handlinger, at vi bliver retfordige" (Aristoteles 2000, s. 55:1103b). 
Det blev imidlertid betonet, at det ikke var målet om den dydig karakter, der skulle udgøre drivkraften, da dette ville gøre borgerne til blotte midler i de studerendes eget selvudviklingsprojekt, men derimod ønsket om at gøre det gode. Dette repræsenterer ifølge Aristoteles et mål i sig selv og er som sådan også meningsfuldt i sig selv.

Ifølge Aristoteles er menneskets natur dobbelt, idet det både er et tænkende og handlende væsen. Han opererede derfor med to slags dyder. De intellektuelle og de praktiske dyder. Hvor de intellektuelle dyder kan forstås som perfektion af tænkning, kan de praktiske dyder også kaldet karakterdyderne, forstås som perfektion af handling.

Dette projekt vedrørte primært handling og altså de praktiske dyder, som ifølge Aristoteles består i en kombination af begær og fornuft. Begær kan forstås som viljen til og bestræbelsen på at handle vel, men denne stræben må imidlertid gå hånd i hånd med fornuften i form af den intellektuelle dyd phronesis også kaldet praktisk klogskab eller dømmekraft. Det er således den praktiske klogskab, der sikrer det rette valg af handling f.eks. i balancen mellem for lidt og for megen tålmodighed. Ifølge Anna-Marie Pahuus og Cecilie Eriksen er forudsætningen for dannelsen af såvel de praktiske dyder som den praktiske klogskab i begge tilfælde; "..en opmcerksomhed over for verden, en vilje til at loere af erfaringen og nogle sociale og politiske omgivelser, som tillader og norer denne opmoerksomheds og viljes udfoldelse." (Eriksen og Pahuus 2011, s. 46)

Projektet var et forsøg på at skabe en sådan ramme, der tillod og nærede netop denne opmærksomheds- og viljesudfoldelse med henblik på at understøtte udviklingen af de studerendes etiske forholdelsesmåder og professionelle dømmekraft i praksis.

\section{Projektets didaktiske form}

Projektets forløb med de studerende begyndte med 3 undervisningsgange af to lektioner, som udgjorde en del af optakten og forberedelserne til de studerendes 2 . praktikperiode.

Rejsemetaforen var en didaktisk inspiration. En dannelsesrejse fordrer motivation og anledning. Derfor måtte det anskueliggøres, hvorfor det er pædagogisk meningsfuldt og relevant at drage på opdagelse i et så umiddelbart eksotisk fænomen som dyder.

Først blev de studerende, i tråd med det ovenfor beskrevne, introduceret til Aristoteles' dydsetik bl.a. med afsæt i en lille introduktionstekst om hans dydsbegreb af Anne Lotte Mørk (2002). Den blev overført til en professionsfaglig kontekst, hvor Aristoteles dydsetisk blev forstået som en fordring til socialpædagogen om altid at bestræbe sig på at handle vel og dermed tjene det gode i den konkrete socialpædagogiske kontekst. Det er en bestræbelse, der over tid potentielt former og perfektionerer socialpædagogens karakter og dømmekraft og kvalificerer dens forudsætninger for at være en socialpædagog, der gør det gode. Dette var 
en opgave, der talte til de studerende, og en rejse, de var motiverede for at drage ud på.

I forlængelse heraf blev den første opgave at forholde sig til følgende: Hvad er ønskværdig socialpædagogisk praksis, når vi undersøger den i lyset af menneskelig godhed? Med andre ord; Hvad er det for karakterdyder, der kendetegner den gode socialpædagog, som handler vel?

Dette blev de studerende sat til at overveje og diskutere i grupper, hvilket bl.a. inkluderede, at de dykkede ned i socialpædagogernes værdigrundlag samt gik på biblioteket og søgte efter foreløbige forståelser og definitioner af de værdier, dyderne skulle realisere. Dette mundede ud i en øvelse, hvor grupperne skulle tegne deres bud på en superpædagog med tilhørende dyder i relation til henholdsvis borgere, pårørende, eksterne samarbejdspartnere og kollegaer samt forklare de andre grupper, hvorfor de fandt netop disse dyder væsentlige i socialpædagogisk arbejde.

Dannelse går via det sociale, og de første opgaver var derfor tænkt som en form for social orientering, der dernæst førte over i en række individuelle opgaver, hvor de studerende i sidste ende skulle vælge en enkelt dyd, som de ville arbejde med i den kommende praktik. Der var altså tale om et mål, der tog afsæt i deres egen person, og hvad de selv fandt betydningsfuldt at arbejde med, hvilket havde stor betydning for de studerendes motivation i processen.

Det blev samtidig tydeliggjort for de studerende, at deres udvalgte dyd ikke nødvendigvis var den, de i sidste ende skulle fokusere på i praktikken; da det var afgørende, at den dyd de primært fokuserede på, forekom udfordrende, aktuel og relevant for dem selv at bestræbe sig på i den konkrete kontekst. Derfor måtte de i starten af praktikken mærke efter og i samarbejde med deres praktikvejleder overveje og vælge en dyd, som dernæst blev begrundet skriftligt i forbindelse med afleveringen af den første af de i alt 3 opgaver, de skulle indsende i løbet af praktikken. 3 studerende skiftede fokusdyd, alle til tålmodighed, hvilket givetvis hang sammen med, at det at forholde sig tålmodigt forekom dem mest udfordrende i starten. Derfor synes det heller ikke entydigt, om det at skifte dyd så relativt tidligt i praktikken var en god ide, men hensigten i projektet var at tage højde for kontekstens betydning.

For at sikre den fornødne overførbarhed mellem de processer, der blev igangsat på uddannelsen og det egentlige dydsarbejde, som skulle finde sted i praktikken, blev praktikvejlederne på praktikstederne inddraget gennem et brev afleveret af de studerende på deres forbesøg samt en introduktion til projektet på en såkaldt læringsplansdag på uddannelsen.

Den indledende del inkluderede således en række didaktiske greb, som medvirkede til at øge de studerendes viden samt skærpe deres bevidsthed og blik for etikkens betydning i god professionsfaglig praksis på et generelt og principielt plan. Praktikken udgjorde i forlængelse heraf muligheden og forudsætningen for refleksion mellem denne viden og den viden, de studerende løbende erhvervede sig 
i praksis gennem handling. Den ene form for viden var altså ikke overordnet den anden.

Med henblik på størst muligt læringsudbytte blev der etableret forskellige former for refleksionsrum, dels løbende med praktikvejlederen, dels rammesat på studiedage med medstuderende, samt med deres studievejleder, i forbindelse med den feedback de fik på deres afleverede opgaver i løbet af praktikken.

\section{De første nøgleerfaringer}

I praktikperioden blev de studerende som nævnt bedt om at aflevere tre opgaver. Disse opgaver fandt deres form i takt med at projektet udviklede sig. De studerende fik individuel skriftlig feedback på alle deres afleveringer. Feedbacken havde ikke til formål at vurdere kvaliteten af det afleverede eller de holdninger og handlinger, de beskrev, men fokuserede på at stimulere den studerendes forsatte refleksions- og øvelsesproces.

De studerendes først afleveringsopgave faldt cirka 7 uger inde i praktikken. Opgaven bestod i, at de studerende skulle beskrive og reflekterer over en praksisfortælling, der vedrørte deres dydsarbejde. I denne periode oplevede mange af de studerende episoder, som de vendte tilbage til i løbet af praktikken, og som således fremstod som nøgleerfaringer, der havde forandret deres forholdelsesmåde.

En af de studerende blev f.eks. ramt af en trang til at tale, når han var sammen med borgere med nedsat sproglig funktionsevne. Stilheden udfordrede hans tålmodighed, som var den dyd han havde valgt, idet han fandt tavsheden akavet.

"Når man sidder der, og man vil hele tiden gerne have et eller andet kørende, men hvor man i virkeligheden jo egentlig får mere ud af bare at sidde og tie stille".

På baggrund af feedback og refleksion forsøgte han at optræde mere tålmodigt og afventende, hvilket gav plads til at registrere borgernes egentlige behov. Gennem selvoverskridelse i form af et brud med den habituelle adfærd og tidligere erkendelse af stilhed som noget akavet, erhvervede den studerende sig herved en ny mere tålmodig forholdelsesmåde. Lignende erfaringer var gennemgående i materialet fra de studerende. Selvoverskridelsen føltes akavet i starten, men blev også forbundet med tilfredshed, når den nye personlige forholdelsesmåde havde indfundet sig. En anden studerende skrev således:

\section{"Jeg har altid voeret den stille type, men da kommunikation var min dyd, har jeg fokuse- ret ekstra meget på den. Det har virkelig hjulpet meget på min nervøsitet. Jeg er begyndt at føle, at jeg nogle gange snakker for meget."}

Inden praktikken var det karakteristisk, at de studerende var optaget af, hvorvidt de ville kunne være f.eks. nærværende eller tålmodige overfor borgerne, men de fleste erfarede hurtigt at kvaliteten af praksis i lige så høj grad handlede om, hvorvidt de formåede at udvise nærvær og tålmodighed overfor sig selv. 
"Jeg så det meget som vœrende sådan, at det skulle vœere overfor den her målgruppe, at jeg skulle voere tålmodig, at det var på den måde, at jeg skulle udføre det. Men det er lige så meget mig som professionel, at jeg sådan skal have tålmodighed med."

Arbejdet med dyderne rettede altså de studerendes opmærksomhed mod såvel deres selv- som verdensforhold og relationen mellem disse.

Det erfarede en af de studerende, idet hun i starten blev ramt af en utilstrækkelighedsfølelse, når det ikke lykkedes hende at udføre de daglige rutiner indenfor tidsplanen. Den studerendes tålmodighed med sig selv og tillid til egne kompetencer steg imidlertid betydeligt gennem praktikken.

Forløb, der forandrer og former de studerendes selv- og verdensforhold, findes utvivlsomt i mange praktikker uafhængigt af en sådan bevidst dydsbestræbelse. Sidstnævnte studerende beskrev imidlertid hvor stor en betydning hendes bestræbelse på at handle tålmodigt havde haft som omdrejningspunkt for disse refleksioner og fremfor alt for hendes bevidsthed om, hvorledes hun fremstod i mødet med borgeren, hvad angik f.eks. kropssprog og toneleje samt hendes måde at tøjle sin indre utålmodighed på igennem dybe vejrtrækninger, at tælle til ti m.m. Det gode resultat hang i dette tilfælde i høj grad sammen med, at vejlederen formåede at skabe den ramme, indenfor hvilken den studerende turde overskride sin egen selvforståelse; altså en ramme, der nærede den studerendes viljesudfoldelse og mod på selvvirksomhed.

\section{Om at bevare modtageligheden og inddrage andre}

I forlængelse af læsningen af de studerendes første afleveringer, meldte der sig et spørgsmål om, hvorvidt de studerende ville kunne opretholde den modtagelige og selvvirksomme forholdelsesmåde, når de først følte, at de mestrede dyden i de daglige rutiner. Der blev derfor tilføjet en række spørgsmål for at styrke en mere fænomenologisk inspireret optagethed af dyden og af detaljerne i de konkrete situationer. Der var dog også studerende, der selv formåede at bevare nysgerrigheden qua deres evne til at stille spørgsmål og derved så at sige åbne 'teksten' på ny. En af de studerende, der havde sans for at forundres og stille spørgsmål, beskrev en erfaring, hun gjorde sig i et såkaldt "snoezelrum", hvor sansestimulationen kan tilpasses den enkelte borger. Borgeren var i dette tilfælde en pige med multihandicap. Den studerende skrev:

"Det faktum, at min blotte tilstedevcerelse i rummet var nok for hende, gjorde, at min interesse $i$ dyden (ncervcer) pludseligt fik endnu en side - gav mig mulighed for at stille spørgsmål/reflektere på en ny måde”.

I kraft af den studerendes modtagelighed opstod en skærpet selvvirksomhed og nysgerrighed, som fik den studerende til at stille spørgsmål som: "Kan man vore fysisk noervorende uden at vore det mentalt $i$ arbejdet med borgeren? Er norvor det samme som tryghed? Er det underordnet, hvem der udviser norvor?" 
Disse og andre spørgsmål delte hun med sine kollegaer gennem en fælles bog, hvor alle medarbejdere kunne respondere og reflektere over disse og nærværets betydning for det pædagogiske arbejde. På spørgsmålet om, hvorvidt man kan være fysisk nærværende uden at være det mentalt i arbejdet med borgeren, svarede en af de ansatte f.eks.:

\footnotetext{
"I princippet vil jeg mene nej. Fordi for mig er det at voere noervcerende eunen til at rette sin psykiske energi mod et andet menneske! .....Dog toenker jeg, at man i små korte perioder kan vcere mentalt fravoerende - det krcever dog at relationen til eleven allerede er der, så trygheden ved hinanden og situationen er der i forvejen".
}

På baggrund af eksperimenterende handlinger, refleksioner og denne type feedback konkluderede den studerende, at pigen havde behov for den studerendes nærvær i form af tilstedeværelse og opmærksomhed, men uden at dette kom til at virkede overstimulerende. Det rette nærvær i relation til pigen i denne konkrete kontekst ville derfor typisk bestå $\mathrm{i}$ at sidde stille på en stol med ryggen til pigen, men med mental opmærksomhed. En forholdelsesmåde, den studerende ikke tidligere havde forbundet med nærvær. Den studerendes sans for at forholde sig undrende og selvvirksomt blev gennem den fælles refleksionsbog næret af personalegruppen, hun indgik i.

\section{Om at bryde med normen, og den praktikbaserede varditilegnelses begraensning}

En af praksisfortællingerne omhandlede dyden tålmodighed og beskrev en episode, hvor den studerende skulle have en voksen beboer med på tur sammen med en anden borger. Den studerende havde fulgt rutinerne og forberedt beboeren i god tid, da beboeren havde en autismespektrumforstyrrelse og lang latenstid. Denne dag ville beboeren imidlertid ikke med, da han umiddelbart var i dårligt humør. Den studerende vidste, at reglen var, at man slukkede for beboerens musik for at markere, at en ny aktivitet nu gik i gang. Situationen udfordrede imidlertid både beboerens og den studerendes tålmodighed, og den studerende valgte derfor at gøre noget andet. Hun tog en chance og lod musikken spille som borgeren ønskede. Hendes fornemmelse og forhåbning var, at ved at lade musikken spille, ville stemningen ændre karakter og smitte af på borgerens humør. Det var præcis, hvad der skete, indtil en kollega kom ind, hørte musikken, og gik direkte hen og slukkede for den med henvisning til den aftalte regel.

Eksemplet viser, hvorledes kompleksiteten i relation til at forvalte dyden stiger i takt med antallet af personer og forhold, der skal udvises tålmodighed over for og tages hensyn til; en problematik der gik igen i de studerendes beskrivelser. For denne studerende blev oplevelsen en nøgleerfaring i forhold til overvejelser om, hvad der kan forsvares etisk som pædagog, og hvilken pædagog den studerende ønskede at være. 
Når pædagogik beskrives som en eksperimenterende handlings- og erkendelsesform, så fordrer det pædagogens blik for og mod til at eksperimentere med egen forholdelsesmåde og praksis. Det er dog næppe alle studerende, der formår dette indenfor en institutionel ramme, hvor de ønsker at stå sig godt med de nye kollegaer og ikke nødvendigvis har forudsætningerne til at sætte spørgsmålstegn ved den gældende praksis. En svaghed ved dydsarbejdet kan derfor være, at de studerende risikerer at forstå, vægte og virkeliggøre dyderne indenfor rammerne af en institutionel kultur, der ikke er efterlignelsesværdig. Dette er en kendt problematik i relation til mesterlæring, som gerne er traditionsformidlende, også når det gælder normer og fordomme, men ikke nødvendigvis tidssvarende og udviklingsorienteret (Wackerhausen 1997). Det gælder også de pædagogiske praktikinstitutioner, hvor der kan være stor forskel på definitionen af god praksis og dermed, hvordan man mener dyderne bør vægtes og realiseres.

Derfor er et kritisk perspektiv i forhold til det lærte vigtigt. Praktikkens studiedage, hvor de studerende var tilbage på uddannelsen, spillede således en væsentlig rolle. Her delte de studerende deres erfaringer, og de fik mulighed for at udfordre hinanden på hinandens forskellige opfattelser af, hvad der kunne forstås som at handle vel - eller med andre ord en vel realiseret dyd. En studerende sagde således i en evaluering af forløbet:

"Jeg synes, det har vaeret virkeligt givende, det der med at vi sådan har drøftet vores erfaringer på studiedagene. Det har givet noget tilbage. Det at man sådan har kunnet få nogle andre perspektiver."

\title{
Meningsfuldt i sig selv
}

I tråd med Aristoteles tanker gav flere studerende direkte og indirekte udtryk for det forhold, at dydsarbejde er meningsfuldt i sig selv. En skrev:

\begin{abstract}
"Jeg tæenker bedre og finder bedre løsninger, når jeg besidder og har fokus på min tålmodighed, min ro og mit overskud - og iscer når man kan se, hvordan det smitter af på beboerne, når de spejler sig $i$ mig". En anden skrev: "Det går overraskende nemt med at motivere mig selv til arbejdet med dyden, da jeg kan se, hvordan det påvirker og hjoelper den enkelte borger. Den tilfredsstillelse, som han/hun fo̊r, er rigelig med motivation i sig selv."
\end{abstract}

Projektet blev afsluttet med, at de studerende lavede en evaluering. På negativsiden blev det påpeget, at arbejdet med dyderne var tidskrævende og kunne fjerne de studerendes fokus fra andre opgaver. Samtidig fremhævede de studerende dog også på negativsiden, at det var ærgerligt, at de ikke havde mere tid til dydsprojektet, da de fandt det mere spændende, indholdsrigt og sågar mere relevant end kompetencemålet. Det skyldes ifølge de studerende, at kompetencemålet ikke var selvvalgt, og at de fandt dydsarbejdet helt grundlæggende for pædagogisk arbejde.

På positivsiden tilsluttede alle studerende sig da også følgende udsagn: "Man udvikler sig som menneske og pcedagog". En af de studerende udtrykte det på 
denne måde: "Det har givet mig en følelse af, hvad det er for nogle voerdier, og hvad det er for nogle etiske ting, som jeg går op $i$, og hvad jeg kan stå inde for."

Endelig var der fuld enighed om følgende: "Feedback på det, som er blevet sendt ind, har givet flere perspektiver på dyden" og videre: "Man får konstruktiv feedback, der "tvinger" en til videre refleksion".

Som det fremgår af ovenstående, er de studerende inde på at det at dydsbestræbelser er tids- og opmærksomhedskrævende. Det samme kan siges om underviserens opgave med at give de studerende den feedback, som de vægter højt. Dannelse er ifølge Max Horkheimer kendetegnet ved at være en proces, der er meningsfuld i sig selv. Denne hengivelse forudsætter tid, en tid Horkheimer ikke længere mente var til stede på grund af den instrumentelle tidsånds fornuft (Jepsen 2018). Det samme kan siges at udfordrer sådanne projekters levedygtighed i en målstyret uddannelsesvirkelighed. Ikke desto mindre er projektet blevet implementeret på den socialpædagogiske specialisering i Aalborg omend i en tilpasset form, hvor de studerende modtager skriftlig feedback fra deres studievejleder en gang frem for tre i løbet af praktikken.

\section{Afrunding}

Projektet viser, at det at forbinde de studerendes egen udviklingsproces med dydsarbejde opleves særdeles menings- og betydningsfuldt af de studerende. De studerende oplever at dydsarbejdet øger deres selvindsigt samt skærper og nuancerer deres blik for væsentlige sider af praksis.

I bestræbelsen på at realisere dyden, synes den værdi dyden udtrykker at få karakter af en etisk optik. Dette afføder normative overvejelser hos de studerende over, hvad de kan stå inde for i praksis, hvem de ønsker at være som pædagog, og hvad de må bestræbe sig på for at kunne realisere det gode. Bestræbelsen er tidskrævende, men det gode og afgørende er, at virkeliggørelsen af dyderne opleves som givende, motiverende og fremfor alt meningsfuld i sig selv.

Baseret på de studerendes opgaver og udsagn indikerer projektet således forandringer i de studerendes etiske og pædagogfaglige selv- og verdensforhold. Praktikforløb må generelt formodes at kunne forandre studerendes selv- og verdensforhold. Men projektets tematisering af dydsarbejdet synes at skærpe de studerende personlige bevidsthed om og eget sprog for dydernes betydning i relation til dem selv, andre og verden. Væsentlige værdier i socialpædagogisk arbejde bliver her konkrete og kropsliggjorte gennem dydsbestræbelsen, hvorfor en sådan tematisering af etik i uddannelse fremstår som et relevant og meningsfuldt supplement til den mere skolastiskorienterede undervisning. 


\section{Litteratur}

Aristoteles (2000): Etikken. Frederiksberg: DET lille FORLAG.

Brinkmann, S. (2015): Forståelse og fortolkning. I: Jacobsen, M.H., Lippert-Rasmussen, K., Nedergaard, P. (red.) (2015): Videnskabsteori - I statskundskab, sociologi og forvaltning. København: Hans Reitzels Forlag.

Christensen A.M.S. (red) (2011): Filosofisk etik - Introduktion til normativ etik, praktisk etik og metaetik. Århus: Århus Universitetsforlag.

Flyvbjerg, B. (2001): Making social science Matter - Why Social Inquiry Fails and How It Can Succeed Again. Cambridge: Cambridge University Press.

Ribers, B. (2018): Etiske cirkler. I: Hjort, Kristiansen og Barkholt (red.) Profesjonsetikk. Oslo: Gyldendal Norsk Forlag AS

Jepsen, P. (2018/2017): Hvad var dannelse? Studier I Pædagogisk Filosofi, 6(2), 95-109. https://doi. org/10.7146/spf.v6i2.101780

Klafki, W. (2011/1994): Dannelsesteori og didaktik - nye studier. Århus: Forlaget Klim.

Mørk, A.L. (2002): Aristoteles. Århus: Forlaget Modtryk

Pahuus, A.M. og Eriksen, C. (2011): Hvad er dømmekraft? - den levende arv fra Aristoteles, Kant og Løgstrup. I: Johansen, M.B. og Olesen, S.G. (red.): Professionernes sociologi og vidensgrundlag. Århus: VIASYSTIME.

Straume, I. S.(red.)(2013): Danningens filosofihistorie. Oslo: Gyldendal Norsk Forlag AS.

Von Oettingen, A. (red.)(2018): Empirisk dannelsesforskning - Mellem teori, empiri og praksis. København: Hans Reitzels Forlag

Wackerhausen, S. (1997): The scholastic paradigm and apprenticeship. Skriftserie - Institut for Filosofi, nr. 1, 1997. Århus: Århus Universitet

Wiberg, M. (2016): Dannelsesbegrebets rolle som regulativ ide i teoretisk pædagogik - Dannelsesbegrebet og den pædagogiske forskning. Studier i Pædagogisk Filosofi 5 (1), 81-95.

Wiberg, M. (2018): Den teoretiske pædagogiks bidrag til empirisk forskning i dannelse - Kan man forske i dannelse? I: Von Oettingen, A. (red.) (2018): Empirisk dannelsesforskning - Mellem teori, empiri og praksis. København: Hans Reitzels Forlag 